\title{
The significance of service quality on customer loyalty with corporate image and customer satisfaction as mediators
}

\author{
Maria Aletta Dei Hariyanto \\ Faculty of Business and Economics, University of Surabaya \\ alettadei@gmail.com \\ Dudi Anandya \\ Faculty of Business and Economics, University of Surabaya \\ dudi@staff.ubaya.ac.id
}

Received: June, 2021; Accepted: September, 2021; Published:

September, 2021

DOI: https://doi.org/10.24123/imb.v20i2

\begin{abstract}
This study seeks to reveal the effect of service quality on customer loyalty mediated by corporate image and customer satisfaction at restaurant $X$ in Surabaya. Data were collected using a questionnaire for each variable, on 150 subjects with the characteristics of a minimum age of 19 years, and a minimum education of senior high school. Data were collected and analyzed using the SEM method with the help of SPSS AMOS 21 software. The results showed that service quality has an influence on customer satisfaction, through corporate image, which in turn affect customer loyalty. Corporate image mediator is fully functional because there is no direct relationship between service quality and customer satisfaction. This shows that consumers feel satisfied not directly caused by service quality, but good service quality form a positive corporate image which then make consumers feel satisfied, ultimately affecting loyalty.

Keywords: service quality, corporate image, customer satisfaction, customer loyalty.
\end{abstract}

\begin{abstract}
Abstrak
Penelitian ini mengungkapkan pengaruh service quality terhadap customer loyalty dengan dimediasi oleh corporate image dan customer satisfaction pada restoran $X$ di Surabaya. Pengambilan data menggunakan kuesioner untuk masing-masing variabel, pada 150 subyek dengan karakteristik usia minimal 19 tahun, dan pendidikan terakhir minimal SMA. Data dikumpulkan dan dianalisis menggunakan metode SEM dengan bantuan software SPSS AMOS 21. Hasil penelitian menunjukkan bahwa service quality memiliki pengaruh terhadap customer satisfaction, dengan melalui corporate image, yang selanjutnya akan mempengaruhi customer loyalty. Mediator corporate image berfungsi penuh karena tidak ada hubungan langsung antara service quality dengan
\end{abstract}


customer satisfaction. Hal ini menunjukkan bahwa konsumen merasa puas bukan disebabkan secara langsung oleh service quality, tetapi service quality yang baik akan membentuk corporate image yang positif kemudian akan membuat konsumen merasa puas, akhirnya berpengaruh terhadap loyalitas mereka.

Kata kunci: kualitas layanan, citra perusahaan, kepuasan pelanggan, loyalitas pelanggan.

\section{INTRODUCTION}

Economic growth in Indonesia in 2018 increased by $5.17 \%$ which is Indonesia's highest growth achievement since 2014. The biggest contributor to economic growth remains the same as in previous years, namely the service sector. Based on the data from the Indonesian Cafe and Restaurant Entrepreneurs Association (Asosiasi Pengusaha Kafe dan Restoran Indonesia- APKRINDO) the growth of the restaurant industry in Surabaya could reach $20 \%$ per year and in 2019 it had been estimated that it would contribute 5.19 trillion to Regional Original Income, which in fact $40 \%$ of the target has been realized in May 2019.

Even though the restaurant business has bright prospects, intense competition often makes some restaurants decide to go out of their business and only a few are able to survive for a long time in the midst of increasingly fierce industry competition. Restaurants are required to provide something more than its competitors in order to survive in a market with intense competition. Restaurants must be aware that consumers must be satisfied with the services provided and customer loyalty is very important for the continuity of the restaurant.

Restaurant X was established in 1978 and it is one of the many steak restaurants in Surabaya. Restaurant $X$ provides a variety of menus that combine western food with Indonesian flavors ranging from appetizers, main courses, desserts to kids' menus with guaranteed quality, as can be seen from the acquisition of ISO 22000:2005 certification on food safety management systems. Every year, Restaurant $X$ always participates in the Jawa Pos Culinary Award and always wins in each category, such as in 2019 restaurant $X$ managed to get first place in the "Family Restaurant of the Year" which the assessment is no longer based on the popularity of the restaurant but customer satisfaction that includes food quality, service, atmosphere, cleanliness and value for money. The various awards received indicate a good public assessment on the image of restaurant $X$, because the corporate image is abstract but its form can be felt from the assessment, both as a sign of appreciation and respect from the public for the company. Until now, restaurant $X$ has 6 outlets 
spread across Surabaya, however many other steakhouses have also emerged with quality service and image that can compete with restaurant $\mathrm{X}$.

The increasing number of steak restaurants in Surabaya shows the increasing demand for similar restaurants among the community and tightens competition. Restaurant $X$ needs to provide good service to attract and retain its customers, it is important for restaurant $X$ to provide satisfactory service according to customer expectations and at the same time, reflect the image positive company. With satisfied customers and a good corporate image, customers are more likely to revisit restaurant $X$ and become loyal.

The results of research conducted by LiHsien Chi \& ShuYi Chi (2019) on the role of corporate image as a mediator between service quality and customer satisfaction; corporate image partially functions as a mediator. There is a direct influence of service quality with customer satisfaction, as well as an indirect influence, that is through corporate image. The research was conducted in the exhibition service industry. The research by LiHsien Chien \& ShuYi Chi became the basis for research at restaurant $\mathrm{X}$, whether corporate image can be a mediator between service quality and customer satisfaction for the customers of restaurant $X$. Restaurant $X$ has survived since 1978 and is one of the restaurants that has a good image, so that the variable corporate image will be a determinant also for customer satisfaction. The satisfaction of customers who come to restaurant $\mathrm{X}$, whether it is solely determined by the quality of the service or also because the quality of service will further strengthen the corporate image of restaurant $\mathrm{X}$, so it will affect customer satisfaction. Corporate image is the accumulation of all the judgments that consumers have in mind with respect to the properties associated with a particular company. In addition, corporate image also refers to the compilation of all analyzes related to the way a company is recognized and perceived by consumers.

A research conducted by Uddin (2013) examined the relationship between customer satisfaction and customer loyalty as well as customer satisfaction with behavioral intention on electronic household products. The results of his research indicated that customer loyalty had a very significant relationship both with behavioral intention and with customer loyalty. When compared to the coefficients, customer satisfaction had a higher correlation coefficient with customer loyalty than with behavioral intention. Based on Uddin's research, in the research at Restaurant X, a customer loyalty variable was added as the dependent variable. 
This research is also based on the results of research by Umail et al., (2018) which analyzed corporate image on customer loyalty, with customer satisfaction as the mediator. The research showed that corporate image had an effect on customer satisfaction and customer satisfaction also affected customer loyalty. Based on these three studies, the researcher wants to explore the role of corporate image and customer satisfaction as a mediator between service quality and customer loyalty to restaurant $X$ customers. Partially, in looking at the relationship between variables, there will be four relationships, which will be explained below.

Zaim et al., (2010) stated that the role of service quality was widely recognized as an important determinant for the success and survival of organizations in today's competitive environment. Consumers would be more sensitive to the increase in standards in service because it was driven by competitive tendencies that have built higher expectations, so that any decrease in customer satisfaction due to poor service quality will be a matter of concern. Research by LiHsien Chien \& ShuYi Chi (2019) showed a significant positive effect of service quality on corporate image, this is supported by Wu's research (2018) which stated that corporate image plays an important role in service organizations, because service quality affected corporate image, which in turn in turn, generate customer satisfaction. Based on this description, the researcher proposes hypothesis 1: Service quality has a positive influence on corporate image.

Research proposed by Rosa et al., (2002) showed that corporate reputation which had described through corporate image had a close relationship with customer satisfaction. This research is supported by research by Walsh et al., (2006) which showed the same result, namely that corporate image had a positive relationship to customer satisfaction. The increase in corporate image will be able to influence consumer behavior positively, because consumers perceive that the services provided by the company are in accordance with the image they have, so it is hoped that the company can continue to maintain a positive corporate image in the eyes of consumers.

Corporate image is the most influential indicator on customer satisfaction. It is needed by the company as a strength to increase competitive advantage, a high corporate image will be able to increase customer satisfaction which will later create customer loyalty in order to be able to survive in increasingly fierce competition (Ene \& Ozkaya, 2014). The research found that corporate image significantly affects customer satisfaction. Therefore, companies should specifically focus on building long-term profitability with customers as a competitive advantage in the 
market. This research is supported by the research of Ene \& Ozkaya (2014) which explained the same result, namely that corporate image had a positive relationship to customer satisfaction. Based on this description, hypothesis 2: Corporate image has a positive influence on customer satisfaction.

Customer satisfaction is important for the company. Companies need to provide maximum service to customers, then the customers are always satisfied with the products and services provided, when customer expectations can be realized, customer satisfaction arises with the products they buy. Anderson et al., (1994) showed a relationship between service quality and customer satisfaction. He stated that improving service quality will derive in customer satisfaction, therefore this relationship must be improved. In addition to Service Quality towards Customer Satisfaction, it revealed that innovation in improved service quality will create consumer satisfaction, the same thing is shown in the research of Kasiri et al., (2017). The results showed that the service industry could increase customer satisfaction through service quality. Therefore, the researcher proposes hypothesis 3: Service quality has a positive influence on Customer Satisfaction.

Bloemer \& Ruyter (1998) indicated that customer satisfaction is directly related to customer loyalty. Customer satisfaction can be owned without having to result in loyalty, but it is difficult or even impossible to have customer loyalty without satisfaction (Mohsan et al., 2011). Kurniasih (2012) stated that to grow customer loyalty, service providers must first give satisfaction to their customers. In the research of Shi et al., (2014) it was found that customer satisfaction had a positive effect on customer loyalty. Based on this, the researcher proposes hypothesis 4: Customer satisfaction has a positive influence on customer loyalty.

\section{RESEARCH METHODS}

This study has 4 variables, namely service quality which is an exogenous variable or as an independent variable, corporate image, and customer satisfaction as a mediator; and the last is the dependent variable, namely customer loyalty.

According to Kotler \& Keller (2016) service quality is the totality of features and characteristics of a product or service based on its ability to fulfill or implied needs. Parasuraman (1998) stated 5 dimensions of service quality, namely: Tangibility, Reliability, Responsiveness, Assurance and Empathy. In this study, service quality is the perception of restaurant $X$ customers on the 5 service dimensions proposed by Parasuraman, those 
are tangibility, teliability, tesponsiveness, assurance and empathy.

Based on Wu (2018) Corporate Image is a number of beliefs, attitudes and impressions towards organizations that play an important role in service organizations, because service quality affects corporate image, which in turn, results in customer satisfaction. Corporate image can be measured through 3 indicators consisting of corporate identity, corporate reputation and image towards competitor. In this study, corporate image is defined as a number of beliefs, attitudes and impressions towards the restaurant $X$, which consists of 3 indicators according to $\mathrm{Wu}$ (2018).

Customer satisfaction is a person's feeling of pleasure or disappointment, which comes from comparing the perceived performance or product results with their expectations (Kotler \& Keller, 2016), In a study conducted by Lee et al., (2017) Customer satisfaction could be measured through overall satisfaction, confirmation of expectation and performance versus ideal. In this study, customer satisfaction is a customer's assessment of products (goods and services); assessing whether the product has met the needs or expectations of restaurant $\mathrm{X}$ customers, measured using three indicators from Lee et al., (2017).

As stated by Kotler \& Keller (2016), customer loyalty is a deeply held commitment to repurchase a preferred product or service in the future despite situational influences and marketing efforts that have the potential to cause behavior change. According to Shi et al., (2014), the indicators that define customer loyalty are repurchase ntention, recommendation intention, word of mouth Intention and preference. In this study, customer loyalty is defined as a commitment to repurchase or assign restaurant $X$ services as consistently preferred, as measured by 4 indicators from Shi et al., (2014).

Items on each dimension of the four variables can be seen from the following table.

Table 1. Items on each dimension and variable

\begin{tabular}{lll}
\hline \multicolumn{1}{c}{ Variable } & Dimension & \multicolumn{1}{c}{ Item } \\
\hline Service & Tangible & I feel Restaurant $X$ has a modern design. \\
quality & & The employees of Restaurant $X$ are well- \\
& & dressed and well-groomed. \\
& I find Restaurant X's menu book is visually \\
& appealing. \\
& I find the physical facilities at restaurant X \\
& are attractive. \\
\hline
\end{tabular}


Table 1. Items on each dimension and variable (Cont'd)

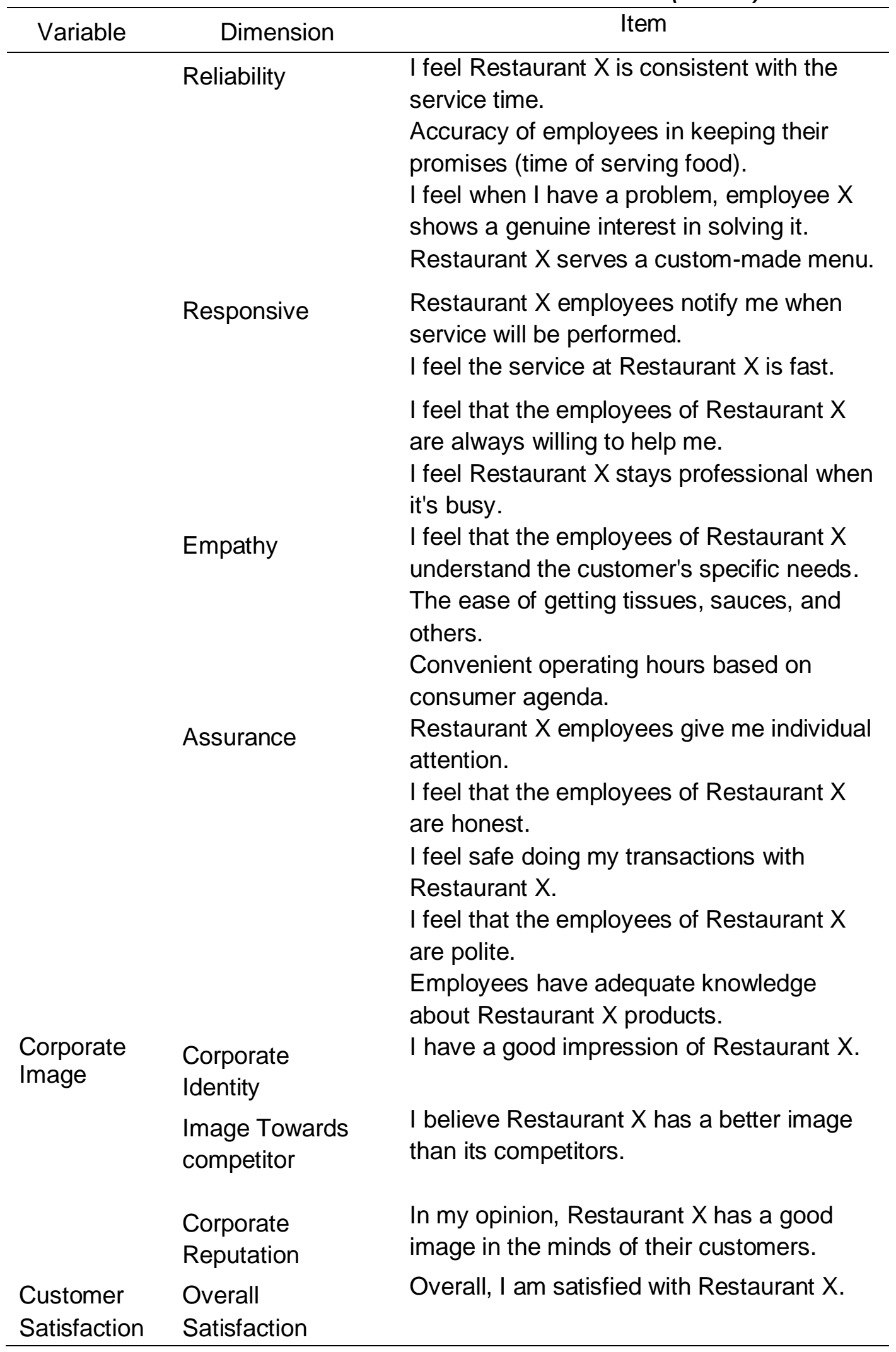


Table 1. Items on each dimension and variable (Cont'd)

\begin{tabular}{|c|c|c|}
\hline Variable & Dimension & Item \\
\hline \multirow{6}{*}{$\begin{array}{l}\text { Customer } \\
\text { Loyalty }\end{array}$} & $\begin{array}{l}\text { Confirmation } \\
\text { Expectation }\end{array}$ & $\begin{array}{l}\text { Restaurant X's performance exceeded my } \\
\text { expectations. }\end{array}$ \\
\hline & $\begin{array}{l}\text { Performance vs } \\
\text { Ideal }\end{array}$ & $\begin{array}{l}\text { Restaurant X's performance exceeds my } \\
\text { hypothetical ideal for similar restaurant } \\
\text { services. }\end{array}$ \\
\hline & $\begin{array}{l}\text { Repurchase } \\
\text { Intention }\end{array}$ & $\begin{array}{l}\text { I will continue to do transaction (being } \\
\text { regular customer) at Restaurant } X \text { for the } \\
\text { next few years. }\end{array}$ \\
\hline & $\begin{array}{l}\text { Recommendation } \\
\text { Intention }\end{array}$ & $\begin{array}{l}\text { I would recommend the Restaurant to } \\
\text { those asking for an opinion on similar } \\
\text { Restaurants. }\end{array}$ \\
\hline & Word of Mouth & $\begin{array}{l}\text { I will say positive things about Restaurant } \\
X \text { to others. }\end{array}$ \\
\hline & Preference & $\begin{array}{l}\text { I prefer to stay subscribed at Restaurant } X \\
\text { even though other Restaurants have } \\
\text { similar or better offers than Restaurant X. }\end{array}$ \\
\hline
\end{tabular}

The following figure shows the relationship of each variable in a research model.

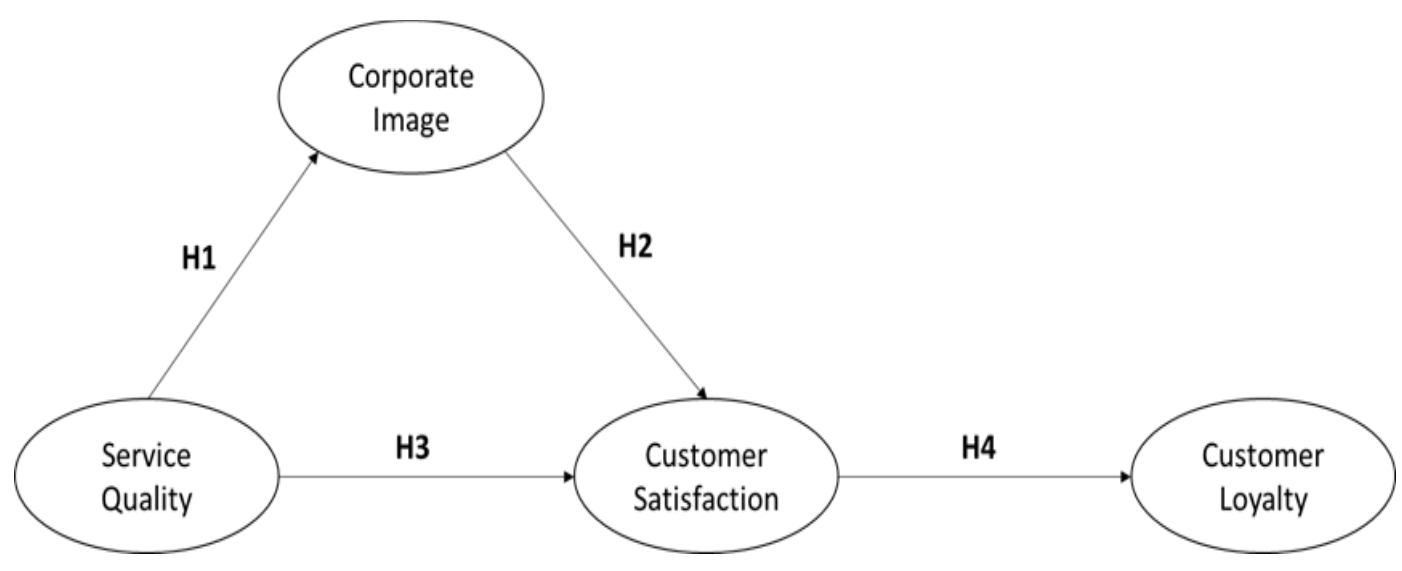

Figure 1. Research Model

In this study, primary data was collected by distributing questionnaires containing five alternative answers provided for each statement measured on five scales, the value closer to 1 means strongly disagree with the statement given, while closer to 5 means strongly agree with the statement. which is given.

The population in this study were consumers of Restaurant $\mathrm{X}$ 
Surabaya, with a minimum age characteristic of 19 years with a background of education from high school, visited Restaurant $X$ in the last 6 months when the research was conducted and consumed Restaurant $X$ 's products. The sampling technique used for this study was nonprobability sampling. This type of convenience sampling is where anyone who can provide information either accidentally or coincidentally meets the researcher, can be used as a sample. In determining the number of samples, at least 5 times higher from the total number of indicator variables used, in this study the number of indicators is 30 , so the number of samples is $30 \times 5=150$ respondents.

The data processing method used in this study was carried out with the help of SPSS version 17.0 software for Windows and AMOS 21. Before data processing was implemented, the validity test was carried out first by calculating the correlation between each question in the questionnaire. The questionnaire was declared valid if the value of rcount rtable with a significance of $\leq 0,05$ (Sugiyono, 2014: 213). After the instrument was tested for the validity, the next step was to test the reliability. The reliability value is $0.00-1.00$. According to Imam Ghozali (2011:48) a construct or variable is said to be reliable if it gives Cronbach's Alpha value $\geq 0.60$.

The next step after the measurements were declared valid and reliable, the data processing was carried out using the Structural Equation Model (SEM) method with AMOS 21 statistical software. SEM is a statistical technique that allows testing of a series of stimulant relationships that is used to explain the relationship between variables in research thoroughly. SEM modeling basically consists of two parts, namely a measurement model that serves to confirm the indicators of a latent variable and a structural model that describes a causal relationship between two or more variables (Ferdinand, 2002).

After testing the suitability of the model (model fit), another evaluation that must be carried out is the assessment of unidimensionality and reliability (Hair et al., 1998, p.611). Unidimensionality is an assumption used in calculating the reliability of the model which shows that a onedimensional model and the indicators used have a good degree of conformity (Hair et al., 1998, p.61), while reliability is a measure of the internal consistency of indicators of a construct. which indicates the degree to which each indicator indicates a common construct or latent factor. There are two approaches that can be taken to assess undimensionality and reliability, namely the construct reliability test and the average variance extracted. 
Construct reliability is a measure of the internal consistency of the indicators of a variable that shows the degree to which the variables are formed. Construct Reliability value is derived from the square of the total value (sum) of standard loading divided by the square of the total value of standard loading plus the value of the sum error.

$(\Sigma \text { standard loading })^{2}$

Construct Reliability

-

$(\Sigma \text { standard loading })^{2}+\Sigma \varepsilon j$

The limit (cut off) of the construct reliability test is accepted if the value is $\geq 0.70$; but the $C R$ value in the range of $0.60-0.70$ is still acceptable, in accordance to Ferdinand (2002, p.64).

Average variance extracted shows the amount of variance of the indicators extracted by the latent construct that was developed.

$$
A V E=\frac{\sum \text { standard loading }}{2}
$$

The AVE value recommended by Ferdinand (2002) is more than or equal to 0.50 .

\section{RESULT AND DISCUSSIONS}

The respondents of this study were 150 people with the largest frequency being in the age range of 36-45 years, which was $32 \%$, and the former education was $\mathrm{S} 1$ which had the largest percentage, that is $53.3 \%$. Before testing the structural model, the measurement model is tested using the Confirmatory Factor Analysis (CFA) method, which begins with the calculation of the Goodness of Fit (GOF) value to assess whether the research model is suitable for analysis using SEM. The following are the results of the model fit test that has been obtained 
Table 2. Measurement model fit test results

\begin{tabular}{lllll}
\hline No. & \multicolumn{1}{c}{ Fit Test } & \multicolumn{1}{c}{ Fit Criteria } & \multicolumn{1}{c}{ Result } & \multicolumn{1}{c}{ Note } \\
\hline $\mathbf{1}$ & CMIN/DF & CMIN/DF $<3$ & 1,680 & Good Fit \\
$\mathbf{2}$ & GFI & GFI $\geq 0,90$ & 0,888 & Marginal Fit \\
$\mathbf{3}$ & RMSEA & RMSEA $\leq 0,08$ & 0,068 & Good Fit \\
$\mathbf{4}$ & CFI & CFI $\geq 0,90$ & 0,900 & Good Fit \\
$\mathbf{5}$ & TLI & TLI $\geq 0,90$ & 0,878 & Marginal Fit \\
\hline
\end{tabular}

CMIN/DF which has a value of $<3$ indicates a good fit model (Hair et al, 2010). In table 2, the value of CMIN/DF $<3$ obtained is 1,680 (good fit). The results of these values indicate that the tested model has met the required model fit criteria. The table above shows the GFI value obtained, which is 0.888 , where the results show that the GFI results meet the model fit criteria and show marginal fit results. The cut off value in RMSEA is acceptable at a value of 0.03 to 0.08 . In table 2 the RMSEA value shown is 0.068 . The results of this value indicate that the model tested is in accordance with the required model fit criteria and shows good fit results. The criteria for a good CFI value is $\geq 0.90$ and the number not less than 0.8 and 0.9 is called a marginal fit. The table above shows the results of the CFI value of 0.900 . The results of this value indicate a good fit, so that it can be said that the tested model has met the model fit criteria. The TLI value $\geq 0.90$ is a good fit, a number not less than 0.8 and 0.9 is called a marginal fit. In table 2, the TLI value shown is 0.878 . These results show that the TLI value is marginal fit, thus the results already meet the required model fit criteria. After conducting the model fit test on the measurement model, next proceed with the assessment of the standardized loading value

Table 3. Standardized loading value

\begin{tabular}{|c|c|c|c|}
\hline No & Variable & & Standardized \\
\hline & & Indicator & Loading \\
\hline \multirow[t]{5}{*}{1} & Service Quality & $T$ & 0,53 \\
\hline & & $R L$ & 0,86 \\
\hline & & $R S$ & 0,74 \\
\hline & & $E M$ & 0,63 \\
\hline & & $A$ & 0,73 \\
\hline \multirow[t]{3}{*}{2} & Corporate Image & $\mathrm{Cl} 1$ & 0,66 \\
\hline & & $\mathrm{Cl} 2$ & 0,72 \\
\hline & & $\mathrm{Cl} 3$ & 0,77 \\
\hline \multirow[t]{3}{*}{3} & Customer Satisfaction & CS1 & 0,75 \\
\hline & & CS2 & 0,74 \\
\hline & & CS3 & 0,36 \\
\hline
\end{tabular}


Table 3. Standardized loading value (Cont'd)

\begin{tabular}{lccc}
\hline No & Variable & Indicator & $\begin{array}{c}\text { Standardized } \\
\text { Loading }\end{array}$ \\
\hline $\mathbf{4}$ & Customer Loyalty & CL1 & 0,66 \\
\cline { 3 - 4 } & & CL2 & 0,76 \\
\hline & & CL3 & 0,27 \\
\hline & & CL4 & 0,21
\end{tabular}

The minimum standardized loading value to be categorized as good is 0.50 . Of the 15 indicators, there are three indicators that do not meet the minimum standardized loading, namely the CS3 indicator which has a value of 0.36 ; CL3 which has a value of 0.2 ; and CL4 which is 0.21 ; as a result, the three indicators must be aborted because the indicator that has a low standardized loading value means it has a weak contribution to explain the construct or its latent variable. By terminating three indicators, the indicators used are valid indicators or in accordance with the latent construct. After eliminating the three indicators, the measurement test was carried out again with the following results:

Table 4. Measurement model fit test results

\begin{tabular}{lllll}
\hline No. & \multicolumn{1}{c}{ Fit Test } & \multicolumn{1}{c}{ Fit Criteria } & \multicolumn{1}{c}{ Result } & \multicolumn{1}{c}{ Note } \\
\hline 1 & CMIN/DF & CMIN/DF $<3$ & 2,179 & Good Fit \\
2 & GFI & GFI $\geq 0,90$ & 0,896 & Marginal fit \\
3 & RMSEA & RMSEA $\leq 0,08$ & 0,080 & Good Fit \\
4 & CFI & CFI $\geq 0,90$ & 0,895 & Marginal Fit \\
5 & TLI & TLI $\geq 0,90$ & 0,862 & Marginal Fit \\
\hline
\end{tabular}

Table 4 shows the measurement results on five items that have met the criteria, namely CMIN/DF, GFI, RMSEA, CFI, and TLI; so it can be said that the tested model has required the model fit criteria.

Table 5. Standardized loading value

\begin{tabular}{llll}
\hline No & \multicolumn{1}{c}{ Variable } & \multicolumn{1}{c}{ Indicator } & $\begin{array}{c}\text { Standardized } \\
\text { Loading }\end{array}$ \\
\hline 1 & Service Quality & \multicolumn{1}{c}{$T$} & 0,53 \\
\cline { 3 - 4 } & & $R L$ & 0,86 \\
\cline { 3 - 4 } & & $R S$ & 0,74 \\
\cline { 3 - 4 } & & $E M$ & 0,63 \\
\cline { 3 - 4 } & & $A$ & 0,73 \\
\hline \multirow{2}{*}{ Corporate Image } & $\mathrm{Cl} 1$ & 0,66 \\
\cline { 3 - 4 } & & $\mathrm{Cl} 2$ & 0,72 \\
\cline { 3 - 4 } & & $\mathrm{Cl} 3$ & 0,77 \\
\hline 3 & Customer Satisfaction & $\mathrm{CS} 1$ & 0,75 \\
\cline { 3 - 4 } & & $\mathrm{CS} 2$ & 0,74 \\
\hline
\end{tabular}


Table 5. Standardized loading value (Cont'd)

\begin{tabular}{cccc}
\hline No & Variable & Indicator & $\begin{array}{c}\text { Standardized } \\
\text { Loading }\end{array}$ \\
\hline 4 & Customer Loyalty & CL1 & 0,66 \\
\cline { 3 - 4 } & & CL2 & 0,76 \\
\hline
\end{tabular}

The table above shows the measurement results that have met the standardized loading requirements $\geq 0.50$, thus the next stage of calculation is carried out validity and reliability testing. Validity and Reliability testing can be done by calculating Average Variance Extracted (AVE) and Construct Reliability (CR) as shown in the table below

Table 6. Construct reliability and average variance extracted (AVE)

\begin{tabular}{|c|c|c|c|c|c|c|}
\hline Variable & Indicator & $\begin{array}{l}\text { Standard } \\
\text { Loading }\end{array}$ & $\begin{array}{l}\text { Standard } \\
\text { loading }^{2}\end{array}$ & $\begin{array}{l}\text { Measurement } \\
\text { Error }\end{array}$ & $\mathrm{CR}$ & AVE \\
\hline \multirow{7}{*}{$\begin{array}{l}\text { Service } \\
\text { Quality }\end{array}$} & $T$ & 0,53 & 0,28 & 0,72 & 0,83 & 0,50 \\
\hline & $\mathrm{RL}$ & 0,86 & 0,74 & 0,26 & & \\
\hline & RS & 0,74 & 0,55 & 0,45 & & \\
\hline & EM & 0,63 & 0,40 & 0,60 & & \\
\hline & A & 0,73 & 0,53 & 0,47 & & \\
\hline & $\Sigma$ & 3,49 & 2,50 & 2,50 & & \\
\hline & $\Sigma^{2}$ & 12,18 & & & & \\
\hline \multirow{5}{*}{$\begin{array}{l}\text { Corporate } \\
\text { Image }\end{array}$} & Cl1 & 0,66 & 0,44 & 0,56 & 0,26 & 0,26 \\
\hline & $\mathrm{Cl} 2$ & 0,77 & 0,59 & 0,41 & & \\
\hline & $\mathrm{Cl} 3$ & 0,72 & 0,52 & 0,48 & & \\
\hline & $\Sigma$ & 2,15 & 1,55 & 1,45 & & \\
\hline & $\Sigma^{2}$ & 4,62 & & & & \\
\hline Customer & CS1 & 0,75 & 0,56 & 0,44 & 0,71 & 0,56 \\
\hline Satisfactio & CS2 & 0,74 & 0,55 & 0,45 & & \\
\hline \multirow[t]{2}{*}{$n$} & $\Sigma$ & 1,49 & 1,11 & 0,89 & & \\
\hline & $\Sigma^{2}$ & 2,22 & & & & \\
\hline Customer & CL1 & 0,66 & 0,44 & 0,56 & 0,67 & 0,51 \\
\hline \multirow[t]{3}{*}{ Loyalty } & CL2 & 0,76 & 0,58 & 0,42 & & \\
\hline & $\Sigma$ & 1,42 & 1,01 & 0,99 & & \\
\hline & $\Sigma^{2}$ & 2,02 & & & & \\
\hline
\end{tabular}

The three variables above have met the reliability test requirements which have a $C R$ value $\geq 0.70$ while the customer loyalty variable has a value between $0.60-0.70$ but it is still acceptable. For the validity test, it can be seen that all of the five variables have met the requirements (AVE 0.50). Therefore, this research can be continued to the structural model testing stage. 
As seen from the results in Figure 2, it can be said that the structural model of this research is in accordance with the empirical data. For that reason, this research deserves to be continued to the next stage, that is testing the relationship between variables. The direct effect of this research model can be seen in Table 7 .

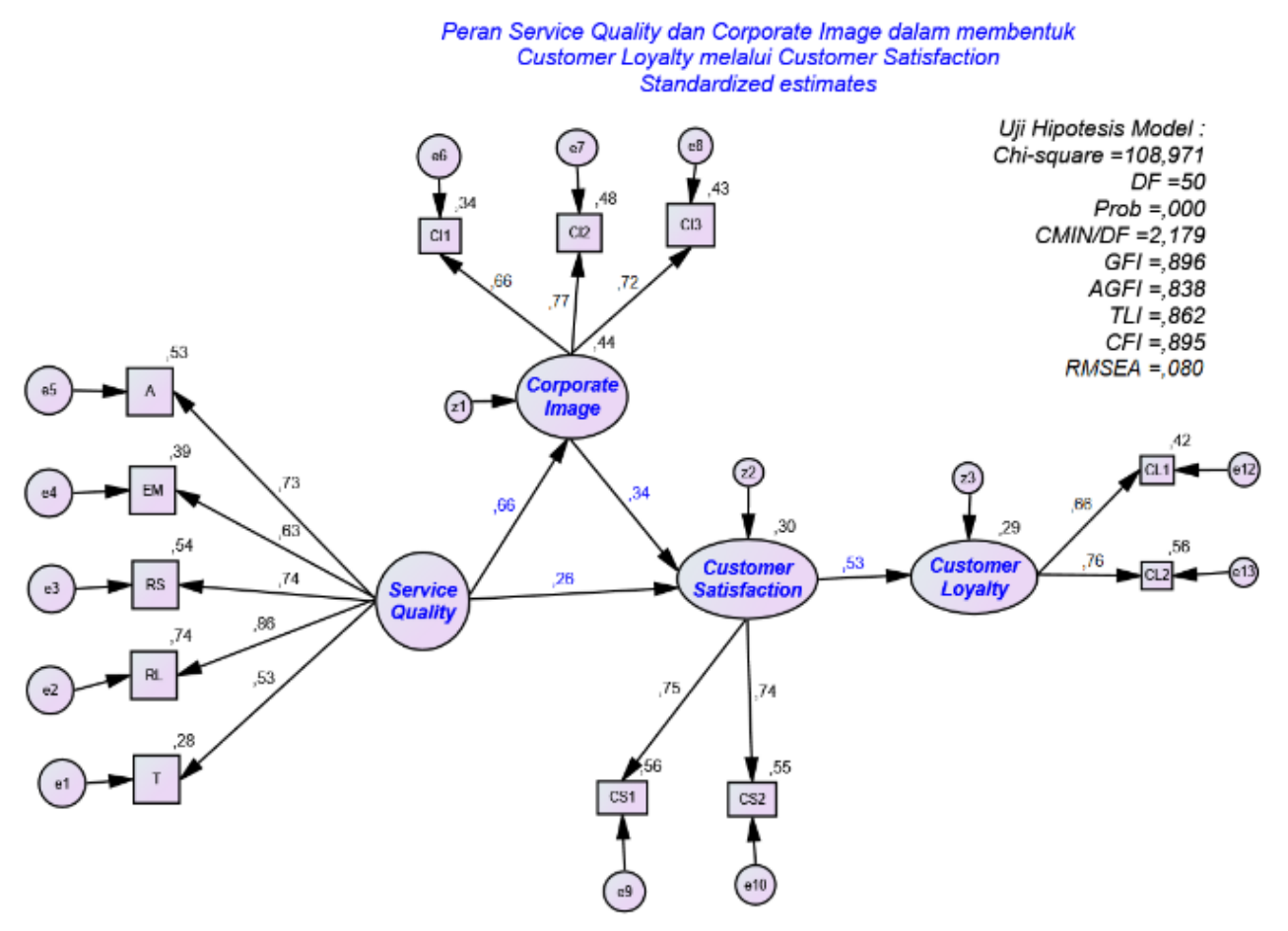

Figure 2. Structural Model

Table 7. Standardized direct effects

\begin{tabular}{|c|c|c|c|c|}
\hline Variable & $\begin{array}{l}\text { Service } \\
\text { Quality }\end{array}$ & $\begin{array}{l}\text { Corporate } \\
\text { Image }\end{array}$ & $\begin{array}{l}\text { Customer } \\
\text { Satisfaction }\end{array}$ & $\begin{array}{c}\text { Customer } \\
\text { Loyalty }\end{array}$ \\
\hline $\begin{array}{l}\text { Corporate } \\
\text { Image }\end{array}$ & 0,662 & 0,000 & 0,000 & 0,000 \\
\hline $\begin{array}{l}\text { Customer } \\
\text { Satisfaction }\end{array}$ & 0,255 & 0,344 & 0,000 & 0,000 \\
\hline $\begin{array}{l}\text { Customer } \\
\text { Loyalty }\end{array}$ & 0,000 & 0,000 & 0,534 & 0,000 \\
\hline
\end{tabular}

The variable that directly affects customer satisfaction is corporate image (0.344) rather than service quality (0.255), especially when viewed from the $p$-value in Table 8, the effect is not significant $(p>0.05)$. 
Table 8. Relationship between variables

\begin{tabular}{|c|c|c|c|c|}
\hline No. & Hypothesis & $\begin{array}{c}\text { Critical } \\
\text { Ratio }\end{array}$ & $\mathrm{P}$-value & Description \\
\hline 1 & $\begin{array}{l}\text { Service Quality } \\
\text { has a positive } \\
\text { effect on } \\
\text { Corporate Image } \\
\text { (H1) }\end{array}$ & 4,279 & $* * *$ & $\begin{array}{l}\text { Accepted, } \\
\text { significant. }\end{array}$ \\
\hline 2 & $\begin{array}{l}\text { Corporate Image } \\
\text { has a positive } \\
\text { effect on } \\
\text { Customer } \\
\text { Satisfaction (H2) }\end{array}$ & 1,992 & 0,046 & $\begin{array}{l}\text { Accepted, } \\
\text { significant }\end{array}$ \\
\hline 3 & $\begin{array}{l}\text { Service Quality } \\
\text { has a positive } \\
\text { effect on } \\
\text { Customer } \\
\text { Satisfaction (H3) }\end{array}$ & 1,634 & 0,102 & $\begin{array}{l}\text { Rejected, } \\
\text { not significant }\end{array}$ \\
\hline 4 & $\begin{array}{l}\text { Customer } \\
\text { Satisfaction has } \\
\text { a positive effect } \\
\text { on Customer } \\
\text { Loyalty }(\mathrm{H} 4)\end{array}$ & 3.518 & $* * *$ & $\begin{array}{l}\text { Accepted, } \\
\text { significant }\end{array}$ \\
\hline
\end{tabular}

The indirect effect (take a role as mediator) in this research model can be seen in Table 9.

Table 9. Standardized indirect effects

\begin{tabular}{|c|c|c|c|}
\hline Service Quality & $\begin{array}{c}\text { Corporate } \\
\text { Image }\end{array}$ & $\begin{array}{l}\text { Customer } \\
\text { Satisfaction }\end{array}$ & $\begin{array}{c}\text { Customer } \\
\text { Loyalty }\end{array}$ \\
\hline $\begin{array}{l}\text { Corporate } \\
\text { Image }\end{array}$ & 0,000 & 0,000 & 0,000 \\
\hline $\begin{array}{l}\text { Customer } \\
\text { Satisfaction }\end{array}$ & 0,228 & 0,00 & 0,000 \\
\hline $\begin{array}{l}\text { Customer } \\
\text { Loyalty }\end{array}$ & 0,258 & 0,184 & 0,000 \\
\hline
\end{tabular}

From Table 9, the variable that has an indirect effect on customer satisfaction is service quality (0.228). Meanwhile the variable that has an indirect effect on customer loyalty is corporate image (0.184) because even though the service quality is 0.258 , the direct influence between service quality and customer satisfaction is not significant. Based on the structural model and the results in tables 7 to 9 , it can be seen that 
corporate image role as a mediator in full as well as the role of mediator customer satisfaction from corporate image with customer loyalty.

In detail, the relationship between variables in the model is as follows; service quality has an influence on corporate image. it can be seen from the critical ratio value of 4.279 with a $p$ value less than 0.05 , namely $p \leq 0.01$. The results of this study are in accordance with the results of previous research conducted by LiHsien Chien \& Shu Yi Chi (2019) which stated that "A significant positive effect of service quality is on the corporate image is confirmed" which is also supported by research by Yilmaz \& Ari (2017) and Zameer et al., (2018) who found the same research results, where service quality has a positive effect on corporate image. Restaurant $X$ is known as a restaurant that has been around for a long time and has a pretty good impression in the eyes of the public. Customers who come already have good expectations of the service and quality of Restaurant $X$, so the services provided do not directly affect customer satisfaction, but will affect the customer's impression of the restaurant, if the service provided is good then the customer's impression of restaurant $X$ will be better, and vice versa.

Corporate Image is also confirmed to significantly affect customer satisfaction at restaurant $X$ Surabaya. This can be identified from the Critical Ratio value of 1.992 with $p$ value $\leq 0.05$. This is similarly found in research by LiHsien Chien \& Shu Yi Chi (2019) which found that Corporate Image has a positive effect on customer satisfaction. Companies that have a good corporate image will not only make customers choose the services they provide but will also increase customer satisfaction, Restaurant X has been established since 1978, so that the majority of consumers who come already have the image that Restaurant $X$ has a good image in the eyes of consumers and community because they are able to survive for a long time in the midst of intense competition in the restaurant industry. This positive image will affect consumer satisfaction where consumers will feel satisfied when making purchases at Restaurant $X$ which already has a positive image.

Customer Satisfaction is also proven to have an effect on customer loyalty at restaurant $X$. This can be observed from the critical ratio value of 3.518 with $p$ value $\leq 0.01$. The results of this study are in line with previous research conducted by Shi et al., (2014) where customer satisfaction is justified to have an effect on customer loyalty. Uddin (2013) also stated that "When customers are highly satisfied they become highly loyal to that particular brand. Higher level of satisfaction influences customers to be loyal to repurchase and recommended to others", which means that if 
consumers feel very satisfied, consumers will tend to be loyal to the brand. The higher the level of consumer satisfaction will affect consumer loyalty and make repeat purchases and recommend to others. The higher the level of consumer satisfaction with restaurant $X$, the higher consumer loyalty to restaurant $X$ which can be seen from repeated purchases at restaurant $X$ and automatically satisfied consumers will recommend Restaurant $X$ to their relatives.

Different results appear where service quality has no effect on customer satisfaction. This can be viewed from the value of the Critical Ratio which is less than 1.96, which is 1.634 with a $p$ value $>0.05$. The results of this study are not in line with the results of research from LiHsien Chien and Shu Yi Chi (2019) showing that service quality has a positive effect on customer satisfaction. However, in this study, it is in line with the research of Chandra \& Sukmana (2020) which found that service quality has no effect on customer satisfaction. Al-Tit (2015) in his research states that the sub-dimension of service quality does not all have a positive effect on customer satisfaction. There are many factors that can affect restaurant customer satisfaction in addition to service quality such as food quality and the image of the restaurant. Restaurant $X$ has been around for a long time and has a quality service that has been tested from year to year, the good quality of service provided by restaurant $X$ has become common place in the eyes of its consumers, then corporate image is the most important consideration compared to service quality currently which is also considered has little effect on the formation of customer satisfaction.

It can be recognized that corporate image has an important role in this research. The research was conducted at restaurant $X$, which already has a Corporate Image in the Surabaya community as a well-known restaurant. Consumers who come to the restaurant not only consume then will feel satisfied and dissatisfied; moreover, most of the consumers who come are not new consumers, so that the image of the restaurant is already in the minds of consumers. When consumers make purchases and receive services from restaurants, the thing happens is to strengthen or weaken the existing image, not directly affecting customer satisfaction. Once the consumers make purchases, the quality of service they receive will further strengthen the restaurant's image. This will cause consumers to be more loyal because of the experience of satisfaction that is experienced based on the proof of the image that is already owned by the consumer when it comes. This explains the hypothesis which states that there is a direct effect of service quality on customer satisfaction which is not proven. The better service quality will lead to a stronger positive corporate image 
of the restaurant which then results in customer satisfaction which in turn has an impact on customer loyalty.

\section{CONCLUSION}

The role of the image of Restaurant $X$ is important in increasing customer satisfaction and loyalty. Consumer satisfaction is not formed directly from service quality, but must be through corporate image. If the customer feels that the quality provided is getting better, then the customer will increasingly have a positive image of Restaurant $X$ and will make the customer feel satisfied, which will eventually become a loyal customer. Based on the results of this study, if you want to increase customer loyalty, what needs to be done is to increase customer satisfaction due to a positive image of the restaurant.

Although service quality does not have a direct effect on Customer Satisfaction, it does not mean that Restaurant $X$ does not need to pay attention to these variables. To grow customer satisfaction and loyalty, Restaurant $X$ still has to maintain service quality so that it is always excellent, and as a result its image becomes more positive. This research has limitations where the researcher is only conducted in one industry, namely the service industry (restaurants) and does not consider the manufacturing industry. Differences in business processes between the manufacturing industry and the service industry can lead to different findings in the manufacturing industry. It would be more appropriate for further researchers to examine the comparison between the two industries. Future researchers can also make comparisons between restaurants that already have a strong image (such as restaurant $\mathrm{X}$ ) and similar restaurants whose image is not too strong.

\section{REFERENCES}

Al-Tit, A. A. (2015). The Effect of Service and Food Quality on Customer Satisfaction and Hence Customer Retention. Asian Social Science, 11(23), 129-139.

Anderson, E.W., Fornell, C., \& Lehmann, D. R. (1994). Customer Satisfaction, Market Share, and Profitability: Findings From Sweden. Journal of Marketing, 58, 53-66.

Bloemer, J. \& Ruyter, K.D. (1998). On The Relationship Between Store Image, Store Satisfaction and Store Loyalty. European Journal of Marketing, Vol. $32(5 / 6), 499-513$.

Chandra, V.J., \& Sukmana, N.C. (2020). Pengaruh food quality, hygiene dan service quality terhadap repurchase intention melalui customer satisfaction sebagai mediator di restoran open kitchen. Retrieved from http://www.dh.gov.uk/health/files/2012/07/White-Paper-Caring-for-ourfuture-reforming-care-and-support-PDF-1580K.pdf 
Rosa, C., Da Silva, R., Davies, G., \& Stuart, R. (2002). Corporate reputation and competitiveness, London: Routledge.

Ene, S. \& Ozkaya, B. (2014). A study on corporate image, customer satisfaction and brand loyalty in the context of retail stores. Asian Social Science, 10(14), 52-66.

Ferdinand, A. (2002). Structural equation modeling dalam penelitian manajemen. Semarang: Universitas Diponegoro.

Ghozali, Imam. (2011). Aplikasi Analisis Multivariate Dengan Program SPSS. Semarang: Badan Penerbit Universitas Diponegoro.

Hair, J., Anderson, R., Tatham, R., \& Black, W. (1998). Multivariate Data Analysis (Fifth Edition). New Jersey: Prentice-Hall. Inc.

Kasiri, L. A., Cheng, K .T. G., Sambasivan, M., \& Sidin, S.M. (2017), Integration of standardization and customization: impact on service quality, customer satisfaction, and loyalty, Journal of Retailing and Consumer Services, 35, 91-97.

Kotler, P., \& Keller, K. L. (2016). Marketing Management 15th Edition. Pearson Education Limited.

Kurniasih. (2012). Pengaruh harga dan kualitas pelayanan terhadap loyalitas pelanggan melalui variabel kepuasan. Jurnal Administrasi Bisnis, 1(1), 3745.

LiHsien Chien., \& ShuYi Chi. (2019). Corporate image as a mediator between service quality and customer satisfaction: difference across categorized exhibitors. Heliyon, 5, 1-22.

Mohsan, F., Nawaz, M., Khan, M. S., Shaukat, Z., \& Aslam, N. (2011). Impact of Customer Satisfaction on Customer Loyalty and Intentions to Switch: Evidence from Banking Sector of Pakistan. International Journal of Business and Social Science, 2(16), 263-270.

Parasuraman, A., V. A., Zeithml \& L.L., Berry., (1998). SERVQUAL : A Multiple Item Scale for Measuring Consumer Perseption of Service Quality, Journal of Retailing, 64(1), 12-40.

Shi, J., Prentice, C., \& He, W. (2014). Linking service quality, customer satisfaction and loyalty in casinos, does membership matter? International Journal of Hospitality Management, 40, 81-91.

Sugiyono. (2014). Metode Penelitian Pendidikan: Pendekatan Kuantitatif, Kualitatif, dan R\&D. Bandung: Alfabeta.

Tu, Y.T, Li, M. L., \& Chih, H. C. (2013). An Empirical Study of Corporate Brand Image, Customer Perceived Value and Satisfaction on Loyalty in Shoes Industry. Journal of Economic and Behavioral Studies, 5(7), 469-483.

Uddin, M. B. (2013). Investigating the Relationships between Customer Satisfaction, Behavioral Intentions, and Customer Loyalty of Electronic Household Products. African Journal of Management Research (AJMR), 21, 49-6

Wu, H. C., Li, M. Y., \& Li, T. (2018), A study of experiential quality, experiential value, experiential satisfaction, theme park image, and revisit intention, 
Journal of Hospitality and Tourism Research, 42(1), 26-73.

Walsh, G., Dinnie, K., \& Wiedmann, K-P. (2006). How do corporate reputation and customer satisfaction impact customer defection? A study of private energy customers in German. Journal of Services Marketing, 20(6):412420.

Yilmaz, V., \& Ari, E. (2017) The effects of service quality, image, and customer satisfaction on customer complaints and loyalty in high-speed rail service in Turkey: a proposal of the structural equation model, Transportmetrica A: Transport Science, 13:1, 67-90.

Zameer, H., Wang, Y., Yasmeen, H., Mofrad, A. A., \& Waheed, A. (2018), Corporate image and customer satisfaction by virtue of employee engagement, Human Systems Management, 37(2), 233-248.

Zaim, H., Bayyurt, N., \& Zaim, S. (2010). Service Quality And Determinants Of Customer Satisfaction In Hospitals: Turkish Experience. International Business \& Economics Research Journal (IBER), 9(5), 51-58. 